Historia Polski w liczbach. Terytorium. Ludność, red. A. Jezierski, GUS, Warszawa 1993, ss. 206

Pomysł opracowania społeczno-gospodarczej przeszłości Polski w ujęciu statystycznym sięga lat 60 . Inicjatywę tę podjął GUS, a jej efektem było ukazanie się roboczych zeszytów pt. Historyc zny rocznik statystyc zny obejmujący lata 1918-1968. Brak środków uniemożliwił kontynuowanie badań. Ponownie inicjatywę GUS podjął w końcu lat osiemdziesiatych, powołujacc komitet redakcyjny z przewodniczacym Franciszkiem Kubiczkiem. Redaktorem głównym a zarazem opracowujacym materiał po 1918 r. został Andrzej Jezierski (Wydział Ekonomiczny Uniwersytetu Warszawskiego). Prowadzenie prac nad okresem do 1795 r. powierzono Andrzejowi Wyczańskiemu (PAN). Badaniami lat 1795-1918 kierował Juliusz Łukasiewicz (Instytut Historyczny Uniwersytetu Warszawskiego). W skład komitetu redakcyjnego weszli także Cezary Kuklo (Filia UW w Białymstoku), Cecylia Leszczyńska (Wydział Ekonomiczny UW) oraz Andrzej Radźko z wydawnictwa „Pallottinum”. Jan Berger z Centralnej Biblioteki Statystycznej został sekretarzem redakcji.

Owocem paroletnich prac tegoż zespołu było siedem roboczych zeszytów Historii Polski w liczbach ${ }^{1}$ omawiających terytorium i ludność, rolnictwo i leśnictwo, górnictwo, przemysł, budownictwo, dochód narodowy, oświatę, naukę, kulturę, transport i łączność, handel oraz finanse. Jak zapowiada redakcja, kolejne zeszyty robocze będą dotyczyły wojska, wyznań religijnych.

W 1993 r. ukazał się pierwszy zeszyt Historii Polski w liczbach poświęcony ludności i terytorium w wersji już wydawniczej ${ }^{2}$. Od opracowania roboczego różniło go przede wszystkim załączenie szeregu mapek i wykresów. Mapy Polski w ogólnym zarysie ukazują terytorium w różnych płaszczyznach historycznych. Odtworzono je lub przerysowano $z$ innych opracowań. Autorzy serii odeszli od powszechnego i sztucznego w ostatnich dziesiątkach lat pokazywania XIX-wiecznych ziem polskich w granicach po 1945 r. Tym razem terytorium Polski XIX-wiecznej ujęto w granice jakie powstały po 1918 r., tj. między innymi bez Dolnego Śląska i Pomorza Zachodniego. Ustalenie to uzupełniono pojęciem „innych ziem zamieszkałych przez skupiska ludności polskiej”, mając na uwadze Litwę, Białoruś, Ruś oraz Górny Śląsk. Natomiast wykresy czy to struktury ludności w postaci piramid wieku, czy 
też ruchu naturalnego ludności nie są tylko uzupełnieniem tabel, ale same stanowią źródło interesujących informacji.

Omawiany zeszyt, tak jak i całą serię Historii Polski w liczbach, autorzy oparli wyłącznie na materiałach statystycznych juz kiedyś drukowanych oraz na literaturze przedmiotowej. Uznali, że zawarty w nich stan wiedzy jest wystarczający. Z pewnością znalazłoby się sporo wątków historii społeczno-gospodarczej, dla opracowania których pożyteczne byłoby sięgnięcie i do archiwaliów. Tym bardziej że publikowane źródła statystyczne nie są pozbawione licznych wad, na co zwracaja uwagę i sami autorzy ${ }^{3}$.

Pierwsza część zeszytu poświęcona jest okresowi do 1795 r. Otwiera ją omówienie C. Kukli badań demograficznych przeszłości Polski oraz opracowań. Sporo miejsca autor poświęca krytycznym uwagom pod adresem źródeł, zwłaszcza archiwalnych, do demografii historycznej. Autorzy tej części pracy (A. Wyczański, C. Kuklo) mieli najtrudniejsze zadanie. Bardzo często z fragmentarycznych przekazów, niepełnych danych liczbowych, wycinkowych opracowan, trzeba było zestawić tablice ludności i terytorium do olbrzymiego okresu od początków państwa polskiego do rozbiorów. Większość źródeł (archiwaliów) ma charakter pośredni i jest pochodzenia skarbowego. Często bez ustalenia i zastosowania współczynników nie da się wyliczyć podstawowych wielkości demograficznych. Znaczna część współczynników stosowana $\mathrm{w}$ opracowaniach budzi niekiedy wątpliwości. Nie wdając się w polemikę o owych współczynnikach autorzy starali się zamieścić materiał najbardziej wiarygodny i reprezentatywny, nie mając zresztą zbyt dużego wyboru.

Brak źródeł o strukturze ludności wg płci, wieku, wyznania i struktury społeczno-zawodowej dla większości ziem Rzeczypospolitej i większości okresu 1000-1795 autorzy spróbowali zastąpić przykładami niektórych miejscowości i lat: Dobre Miasto w 1695 r., parafia Wieluń w 1791 r., struktura wyznaniowa Gdańska w latach 1631-1800 itp.

Źródeł do badań ruchu naturalnego ludności jest sporo. Niezbyt liczne były natomiast badania w oparciu o księgi parafialne, dlatego autorzy znów mieli trudności $\mathrm{z}$ pokazaniem tego problemu $\mathrm{w}$ tabelach. Urodzenia i zgony oraz przyrost naturalny są zilustrowane jedynie trzema przykładami: parafii Czacz w Wielkopolsce (1600-1799), parafii Świętego Krzyża w Warszawie (1700-1799) i parafii św. Magdaleny w Poznaniu (1710-1799), a więc jednego raczej przypadkowego przykładu wiejskiego i dwóch raczej nietypowych miejskich. Po lekturze tej części opracowania odnosi się wrażenie, że zabrakło w niej jakichś ogólniejszych spostrzeżeń wynikających z zestawienia obok siebie 40 tabel oraz kilku map i wykresów. Czy wytłumaczeniem może być sceptyczna uwaga C. Kukli: „rozwój zaludnienia ziem polskich w epoce przedrozbiorowej mimo wysiłku kilku pokoleń badaczy pozostaje nadal dużą niewiadomą" ? ${ }^{4}$

Drugą część, poświęconą okresowi 1795-1918, otwiera zwięzłe i przejrzyste omówienie źródeł archiwalnych, publikacji oraz badań demograficznych w poszczególnych zaborach autorstwa J. Bergera. Natomiast w kilku uwagach wstępnych J. Łu- 
kasiewicz wskazuje na najczęstsze trudności badawcze nad demografią ziem polskich w XIX w. Następnie materiał liczbowy w tabelach pokazuje podział terytorialny, liczbę ludności w różnych częściach ziem polskich i w różnych przekrojach chronologicznych. Kolejne tabele prezentują ludność Królestwa Polskiego, Galicji i Wielkiego Księstwa Poznańskiego wg płci i wieku. Kilka kolorowych wykresów i piramid wieku świetnie ilustruje tę strukturę.

Struktura ludności wg miejsca zamieszkania (wieś, miasto, osada), wg wyznania i języka, struktura zawodowa oraz ruch naturalny, śmiertelność niemowląt i przeciętne trwania życia - niestety, z powodu braku źródeł zilustrowane są tylko fragmentarycznie za pomoca przykładów. Rozdział zawiera także bilans migracji ludności oraz zmiany ludnościowe (ruch naturalny i zmobilizowani) w okresie I wojny światowej. 72 starannie dobrane tabele oraz kilka wykresów ukazują najważniejsze trendy demograficzne ziem polskiech od trzeciego rozbioru do 1918 r. Spadek śmiertelności oraz wydłużenie życia spowodowały przyrost naturalny (dochodzący do 20, 30 promilli), który J. Łukasiewicz nie waha się nazwać eksplozją demograficzną.

Wraz z powołaniem w 1918 r. Głównego Urzędu Statystycznego, a także innych wyspecjalizowanych instytucji statystyczno-badawczych, dane liczbowe zaczęto zbierać profesjonalnie i w sposób nowoczesny. Wykorzystanie przez badaczy tych danych nie nastręcza dziś żadnych trudności. O źródłach i badaniach napisał we wprowadzeniu J. Berger. Pierwsze tabele i mapy poświęcone są liczbie ludności i podziałom administracyjnym w latach 1918-1990. Struktura ludności wg płci i wieku to kolejne zestawienia tabelaryczne, kolorowe piramidy i inne wykresy w różnych przekrojach chronologicznych. Następne tabele prezentują strukturę ludności w podziale na wieś i miasto, strukturę wg języka i wyznania oraz po raz pierwszy (w całym opracowaniu) strukturę narodowościową. Problem narodowości pokazany w oparciu o spis z $1931 \mathrm{r}$. w opracowaniu pojawia się tylko jeszcze raz dla lat 1946-1947. Późniejsze spisy powszechne z lat 1950 i 1988 nie uwzględniały ani narodowości, ani wyznania, a i późniejsze wydania roczników statystycznych kwestia narodowości też nie interesuje. Autorzy tej części (A. Jezierski, C. Leszczyńska) także pominęli strukturę narodowościową współczesnej Polski. Natomiast całą 169 stronę poświęcili niedzielnym praktykom religijnym (uczęszczający do kościoła i przystępujący do komunii katolicy w 1984 r.) - problemowi z punktu widzenia całości opracowania - wydaje się - dość błahemu.

Kilkanaście tabel opisuje strukturę zawodową w różnych ujęciach problemowych i przekrojach czasowych. 4 tabele dotyczą ruchu naturalnego ludności. Szkoda, że tego ostatniego problemu nie zilustrowano wykresem, tak jak zrobił to J. Łukasiewicz dla Galicji i W. K. Poznańskiego (s. 104, 108). Ostatnie tabele poświęcono zmianom populacyjnym, w tym także stratom ludności w okresie II wojny światowej.

Nie da się, na koniec, uniknąć postawienia pytania o adresata serii Historia Polski w liczbach. Wydaje się, że redakcja przygotowała kolejne zeszyty z myślą głów- 
nie o instytutach naukowych, specjalistycznych bibliotekach, uczelniach. Zapewne praca ta stanie się np. uzupełnieniem źródeł, z jakich muszą korzystać studiujący statystykę historyczną i demografię historyczna. Syntetyczne ujęcie opracowania, czytelny chronologiczno-problemowy układ oraz przejrzysta, wręcz wzorcowa konstrukcja tabel może zdobyć temu wydawnictwu także szerszego odbiorcę.

\section{Jan Godlewski}

\section{PRZYPISY}

1. Historia Polski w liczbach, Zeszyt 1: Terytorium. Ludność, Warszawa 1990; Zeszyt 2: Rolnictwo. Leśnictwo, Warszawa 1991; Zeszyt 3: Górnictwo i przemyst. Budownictwo. Dochód narodowy. Warszawa 1991; Zeszyt 4: Oświata. Nauka. Kultura, Warszawa 1992; Zeszyt 5: Transport. Eiqczność, Warszawa 1995; Zeszyt 6: Handel, Warszawa 1995; Zeszyt 7: Finanse, Warszawa 1996.

2. Historia Polski w liczbach. Terytorium. Ludność, Warszawa 1993.

3. Tamże, s. 51,55 .

4. Tamże, s. 9. 